\title{
The Effect of Human Activities Towards Coastal Dynamics and Sustainable Coastal Management
}

\author{
Nur Hamid ${ }^{1,2}$, Dewi Liesnoor Setyowati ${ }^{1 *}$, Juhadi ${ }^{1}$, Agustinus Sugeng Priyanto ${ }^{1}$, Puji Hardati ${ }^{1}$, Muh Soleh ${ }^{1}$, Nur \\ Rohmah Wijayanti ${ }^{1}$, Elvara Norma Aroyandini ${ }^{3}$ \\ ${ }^{1}$ Faculty of Social Sciences, Universitas Negeri Semarang, Semarang 50229, Central Java, Indonesia \\ ${ }^{2}$ Department of Islamic Community Development, Universitas Islam Negeri Walisongo Semarang, Semarang 50185, Central \\ Java, Indonesia \\ ${ }^{3}$ Faculty of Mathematics and Natural Sciences, Universitas Negeri Yogyakarta, Depok 55281, Yogyakarta Special Region, \\ Indonesia
}

Corresponding Author Email: liesnoor2015@mail.unnes.ac.id

https://doi.org/10.18280/ijsdp.160809

Received: 5 October 2021

Accepted: 6 December 2021

\section{Keywords:}

coastal dynamics, human activities, sustainable coastal management

\begin{abstract}
One of the disasters that often occur in coastal areas is abrasion. Abrasion causes coastal dynamics, including the East Coast of Rembang, Kragan Village, Kragan District, Rembang Regency. From 1975 to 1990, at least 50 meters of land from this area has been lost due to abrasion. This dynamic may become one of the causes of unsustainable management of the coastal environment and its natural resources. Various efforts have been made to overcome abrasion, but abrasion continues to hit this area, even until 2020. Qualitative and quantitative approaches were carried out in this study to discover the coast dynamics and various human activities that may trigger abrasion. Image interpretation, observation, interviews, and questionnaires were used as data collection techniques at three observation points in the Kragan Village area. This study concludes that the beach in Kragan Village has experienced dynamics with a total land loss of 46 meters from 2003 to 2020 . Harmful activities carried out by humans resulted in abrasion so that the coast experienced dynamics. Human activities also affect coastal management, namely the basic principles of integrated coastal management and processes in the management of coastal areas.
\end{abstract}

\section{INTRODUCTION}

Climate and tides are the two causes of disasters in coastal areas. Some of the disasters on the coast are abrasion, rob, availability of clean water, drought, malaria, to a decrease in food production [1]. Today's climate has changed due to global warming. As a result, the air temperature has increased so that the ice in the north and south poles is melting, thus impacting sea levels that have increased. In addition to climate, tides also cause disasters in coastal areas. Tidal conditions cause sea levels to rise above normal conditions due to strong winds and decreased atmospheric pressure [2]. The existence of climate change and extreme tidal conditions will result in the erosion of land on the coast or known as abrasion [3].

Abrasion causes damage to the beach. Among the signs are shoreline damage due to the release of coastal materials, such as sand or clay continuously hit by ocean waves, changes in the balance of sediment transport in coastal waters, or loss of land in coastal areas. The abrasion process is described by Pratikto and Armono [4] that waves occur due to wind blowing on the water's surface. As the waves approach the shore, they begin to rub against the seabed, causing turbulence, which carries material off the beach bed or causes the sand to erode on the beach. The types of beaches will also affect the ease of abrasion. The types of beaches in question are exposure beaches (predominant depositional process), oceanic beaches (predominant abrasion process), and island beaches (beaches that surround small islands)

Diposaptono [5] states that at least five causes of abrasion caused by human activities (anthropogenic) can cause shoreline changes. First, the trapping of longshore sediment transport due to artificial structures such as groins, harbor breakwaters, and reclamation parallel to the shoreline. Second, the emergence of changes in currents due to the presence of buildings on the coast. Third, the reduced supply of sediment from the river due to sand mining, dams on the upstream side of the river, and the drain (removal of river currents). Fourth, sand mining in coastal waters can lead to changes in depth to change current patterns and break waves. Furthermore, fifth is taking natural coastal protectors, namely logging mangrove forests and taking coral reefs.

As an archipelagic country, Indonesia is very vulnerable to the risk of abrasion, whereas one of the provinces in Indonesia that has a high vulnerability to abrasion is Central Java Province. Abrasion in Central Java Province is mainly caused by natural processes [6]. Abrasion in the northern part of Central Java Province causes damage to mangrove ecosystems, seaweed, coral reefs, and ponds (MFF, 2015) [7]. Furthermore, the abrasion that occurred on the north coast of Central Java also caused changes to the coastline [8-10]. Apart from natural factors, abrasion is also caused by human factors. Due to the low level of knowledge and the wrong community perception about abrasion, people take actions that unconsciously trigger the occurrence of abrasion. Some of them are destroying coral 
reefs, mining sand, and cutting down vegetation such as mangroves, which are barriers to abrasion $[2,11,12]$.

One of the regencies in Central Java that is prone to abrasion is in Rembang Regency, especially in Kragan District. Abrasion in this sub-district seems to have become an annual disaster because abrasion occurs almost every year in this subdistrict. This sub-district has experienced abrasion for a long time, which has been recorded since 1975 that abrasion has occurred in this sub-district. From 1975 to 1990, this subdistrict has lost approximately 50 meters of land, which is indicated by the distance between the coast and the mainland was 100 meters, but in 1990 there were only about 50 meters [13]. Until now, abrasion continues to occur in Kragan District, so it is possible that the land on the coast of this sub-district also continues to experience erosion. Based on the Regional Disaster Management Agency data, at least abrasion with great intensity and loss occurred 11 times from 2003 to 2020 with a total loss of more than one billion rupiahs [14].

Abrasion is one of the disasters that threaten the sustainability of coastal areas. Abrasion causes coastal areas to suffer damage, resulting in the degradation of coastal resources [15]. Information about abrasion and its relation to the sustainability of coastal areas must be known by the community so that the community can take a role together with other stakeholders to manage coastal areas in an integrated and wise manner [16]. However, based on the survey conducted, it is known that the community does not yet know that abrasion will be fatal to the sustainability of coastal areas. People only understand the impact of the abrasion disaster from visible impacts, such as the damage to various fishing equipment, the collapse of residential areas, to the sinking of land. However, people do not know that the occurrence of abrasion will also affect the sustainability of the coast for future generations. Coastal sustainability, in this case, is defined as the ability of the coast to meet the needs of people's lives at this time without destroying or reducing their abilities, so that future generations can still utilize natural resources to meet their needs [17].

Therefore, this study was conducted to determine the coast dynamics caused by abrasion on the East Coast of Rembang, located in Kragan Village, Kragan District, Rembang Regency, so that the total loss of land during the period 2003 to 2020 . Given that abrasion is not only caused by natural factors, this study will also identify community activities around the coast that may be a trigger for abrasion. Information about the total loss of land can provide awareness to stakeholders responsible for coastal areas so that they can carry out coastal management in a more sustainable manner and become an illustration for all people in the world that they have the same role to make natural resources sustainable. This research is fundamental to do, considering that through this research, specific knowledge or conclusions will be generated that can influence government policies and community behavior in carrying out disaster prevention efforts and activities that support sustainable development [18].

\section{LITERATURE REVIEW}

\subsection{Humans' activities in coastal area}

Human activities on the coast consist of at least two types, namely beneficial and detrimental activities. Profitable activities include planting mangroves, preserving mangroves, and wisely using natural resources such as sand and coral. Community mitigation efforts by installing various rocks such as limestone and andesite stone, talud, concrete or breakwater walls, relocating buildings, and so on are also beneficial activities that can ultimately prevent abrasion [19-21]. Meanwhile, harmful activities are mining for sand, destroying coral reefs and their habitats, building ponds, constructing buildings that jut into the sea, carrying out intensive coastal development to eliminate habitat, destroying seagrass beds, and coastal reinforcement [22]. According to Joesidawati [23] research, people who do not want to make mitigation efforts by installing beach protectors and carrying out illegal sand mining also contribute to coastal damage with percentages of $30 \%$ and $35 \%$, respectively.

Most people actually already know about the impact of their activities on the sustainability of coastal areas. For example, people on the coast of Sigandu Beach, Batang Regency, Central Java Province, and coastal communities of Kuala Leuge Beach, Peureulak, East Aceh, Indonesia. The community has made various mitigation efforts to prevent more severe coastal damage due to abrasion [3, 24]. The community has also learned about the importance of the mangrove ecosystem in supporting the community's economy and being a coastal protector from abrasion, as has been realized by the community in the Arafura Sea Coast, Merauke Regency, Papua Province. However, the community's weakness is that the mitigation activities they carry out are often not self-initiated but because there is stimulation and support from outsiders [25]. The mangrove and tree planting activities they carried out were also only ceremonial activities, without any further monitoring and evaluation [26].

\subsection{Coastal dynamics}

Coastal dynamics are caused by various factors, such as storms, rising sea levels, floods, and ocean waves. Ocean waves can cause abrasion (over a long period), while storms also cause abrasion (in a short time). The study of coastal dynamics is closely related to the factors that influence it, including the type of beach, sediment analysis, ocean waves, wave transformation, sea-level fluctuations, coastal sediment transport, shoreline changes, and coastal protection systems. Coastal dynamics can be known by studying natural factors in the form of currents, waves, and winds and their relationship with coastal abrasion and accretion. This identification will produce information about coastal changes and their interactions with coastal dynamics [27].

Abrasion and sedimentation are the two processes that are currently most associated with the occurrence of coastal dynamics [28]. Various beaches in Indonesia have experienced dynamics due to abrasion, one of which is Sigandu Beach, Batang Regency, Indonesia. The dynamics on the coast are indicated by two main characteristics, namely changes in coastline and loss of land area. The results of the analysis using Google Earth imagery show that from 2006 to 2014 , the most severe coastline decline occurred in the coastal area of Batang Regency, which was between $70 \mathrm{~m}$ to $110 \mathrm{~m}$. In addition, the land area on the coast has also experienced a reduction, which is around 3.5 hectares in a period of eight years, from 2006 to 2014 [24]. In addition, various regencies in Indonesia, including Kendal and Brebes Regencies, Central Java Province, as well as Bantul and Kulon Progo Regencies, Special Region of Yogyakarta, are also known to have experienced dynamics in their coastal areas. The dynamics on the four beaches are caused by sedimentation as the most dominant cause. Sedimentation in Brebes and Kendal Regencies is 2.2 kilometers and 1.9 kilometers, respectively 


\subsection{Sustainable coastal management}

Coastal dynamics and their main drivers need to be analyzed further. Through this analysis, it will be known about the appropriate management actions. The analysis is carried out specifically on a beach because from one beach to another beach has different characteristics, so different management is needed. Through proper management, the risk of abrasion caused by natural and human factors can be minimized to the maximum [30]. Coastal management must at least consider various aspects such as coastal typology and socio-economic conditions of the community $[3,19]$. The management of a coastal area must also consider the existence of the surrounding coastal coasts because often, protection for a particular coastal area actually results in losses for other surrounding coastal areas [27].

Management of coastal areas is a programmed effort and is carried out in stages with a specific goal. There are at least three main objectives, namely first, the creation of a better economy for coastal communities with broader employment opportunities and more income. Second, the creation of social justice in the form of equal distribution of employment and community prosperity. Third, the preservation of the environment. In general, the purpose of coastal management is to protect and utilize coastal resources by involving the active role of the community, institutions, and government, to create an increase in economic, social, and cultural values in resource utilization $[31,32]$.

Referring to the "Policy on Utilization of Coastal Areas and Small Islands in Relation to Environmental Management," mentioned by the Directorate General of Marine Spatial Management, Ministry of Marine Affairs, and Fisheries of Indonesia, it can be seen about sustainable coastal management. The laws governing the management of coastal and marine areas are Law No. 27 of 2007 and Law No. 1 of 2014 concerning the management of coastal areas and small islands. The sustainable management process consists of activities ranging from planning, utilization, monitoring, and control of human interaction in utilizing coastal resources and small islands. This process is expected to make resources sustainable and improve the welfare of the community and maintain the integrity of the country. In addition, it is also carried out by integrating various collaborations between stakeholders, namely between regional governments, regional governments, between sectors, between the government, the business world and the community, between land and sea ecosystems; and between science and management [33-35].

The sustainability of coastal areas can be achieved if integrated management is carried out. According to the Ministry of Maritime Affairs and Fisheries of the Republic of Indonesia, this management must integrate activities between sectors by coordinating related responsibilities between sectors vertically and horizontally; between fields of science where management is carried out with a multidisciplinary approach; between land and sea environments by taking into account the marine and land ecosystem attachments that affect coastal areas; and between technology and management. The Decree of the Minister of Maritime Affairs and Fisheries No.KEP10/MEN/2012, which is enhanced by Law No.1 of 2014, also mentions the principles of integrated coastal management, including sustainability, consistency, integration, legal certainty, partnership, equity, community participation, openness, and decentralization. The stages in integrated coastal area management are explained through the Decree of the Minister of Marine Affairs and Fisheries No.KEP10/MEN/2012, which is shown in the following Figure 1.

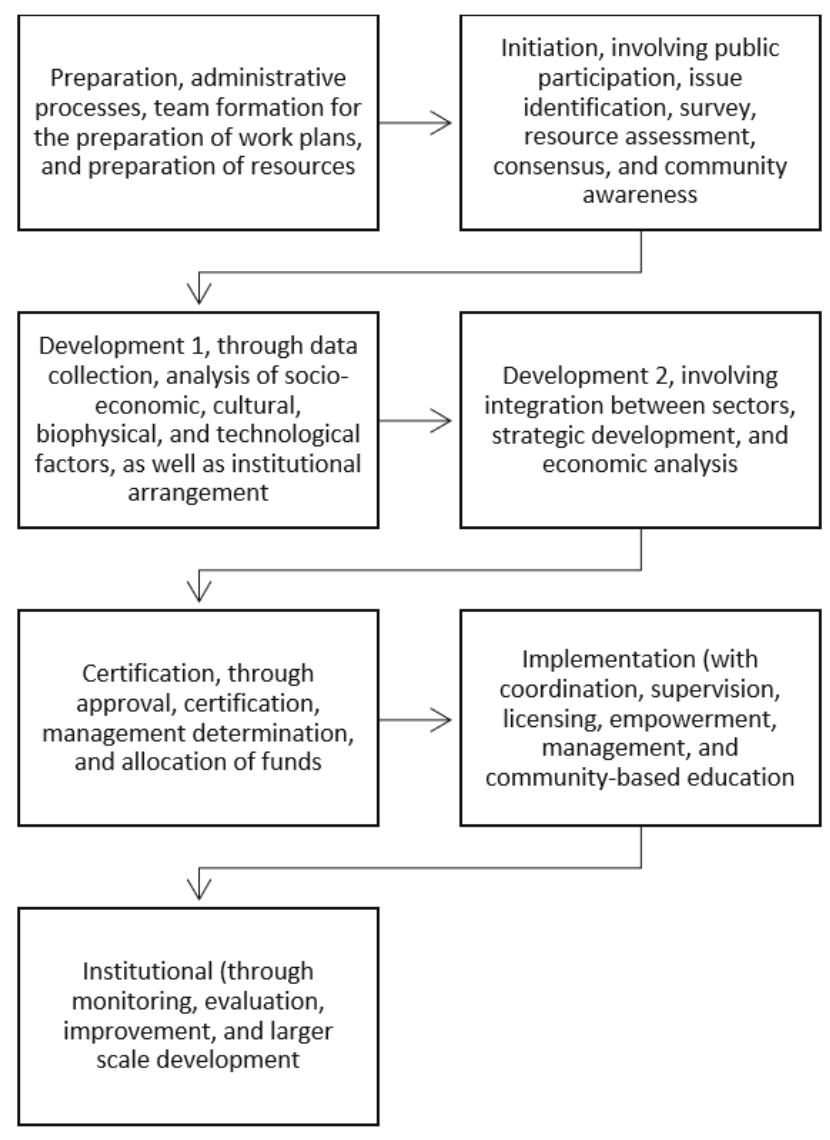

Figure 1. The stages in integrated coastal area management

\section{MATERIAL AND METHODS}

This research is a type of mixed method that combines qualitative and quantitative approaches. The quantitative approach in this study was used to determine the condition of the coast and the loss of land in Kragan Village, as shown in Figure 2, and to determine the knowledge and attitudes of the community towards abrasion. The qualitative approach in this study was carried out to determine the dynamics of the beach in Kragan Village, Kragan District, Rembang Regency, and the human activities that disturb it. The data obtained from the qualitative and quantitative approaches will complement each other so that in this study, valid and accurate data is produced according to the conditions in the field.

The research objects include changes in the coastline of Kragan Village from 2003 to 2020 and human activities that affect the dynamics of abrasion in Kragan Village. The research variables include data on coastal changes, objects affected by abrasion, knowledge of abrasion, attitudes towards abrasion, and abrasion mitigation, as shown in Table 1.

The primary data collection technique used is image interpretation. Image interpretation studies aerial photographs and/or images to identify objects and assess their importance [36]. This study uses ArcGIS software to perform the digitization process in the coastal area of Kragan Village. The image used to study the dynamics of shoreline change is a 
Landsat-5TM image with a spatial resolution of up to 30 meters. Based on historical data from Landsat-5TM imagery, this study provides information about the extent of changes in the coastline of Kragan Village with a comparison of coastline imaging in 2003, 2012, 2016, 2017, and 2020 using the ArcGIS program. Geometric correction is done by looking for an image to image, aiming to be rectified evenly. After the geometric correction is done, the next step is to digitize to determine the coastline. The digitized object is the appearance of the coastline in the image and uses interpretation keys in the form of color, hue, and pattern. After digitizing, further processing is carried out in layouting or displaying maps, charts, tables, and graphic data (original or imported). The next stage is the layout (map view). The layout is the final result that will be displayed in the form of a map.

Supporting data collection techniques are through interviews, documentation studies, observations, and questionnaires. Interviews were conducted on people living in the coastal areas of Kragan Village, especially those that have been affected by abrasion, local governments, and the nearest National Disaster Management Agency. Documentation studies are carried out by assessing previously produced documents in printed and digital documents, newspapers, journals, statistical data, and various previous studies related to the research theme. Observations are carried out by conducting field visits to compare the results of image interpretation with actual natural conditions in the field and observing the daily activities of coastal communities. Questionnaires are used to collect data that will measure people's knowledge and attitudes towards abrasion, where the data becomes the basis for knowing human activities that trigger abrasion. The questionnaire uses statements that are different from interviews, making it possible to use it as a means of triangulating data obtained through interviews and observations.
Table 1. Research variables

\begin{tabular}{|c|c|c|c|}
\hline $\begin{array}{c}\text { Research } \\
\text { Object }\end{array}$ & Variable & Indicator & $\begin{array}{c}\text { Data } \\
\text { Collection }\end{array}$ \\
\hline \multirow{2}{*}{$\begin{array}{l}\text { Coastal } \\
\text { changes } \\
\text { due to } \\
\text { abrasion }\end{array}$} & $\begin{array}{l}\text { Coastal } \\
\text { change } \\
\text { data }\end{array}$ & $\begin{array}{c}\text { Changes in } \\
\text { shoreline and } \\
\text { coastal conditions } \\
\text { over a certain } \\
\text { period (2003- } \\
2020)\end{array}$ & $\begin{array}{c}\text { Image } \\
\text { interpretation }\end{array}$ \\
\hline & $\begin{array}{l}\text { Houses } \\
\text { (objects) } \\
\text { affected by } \\
\text { abrasion }\end{array}$ & $\begin{array}{c}\text { Impact of } \\
\text { shoreline changes } \\
\text { on settlements }\end{array}$ & $\begin{array}{c}\text { Image } \\
\text { interpretation, } \\
\text { observation, } \\
\text { and interviews }\end{array}$ \\
\hline \multirow{3}{*}{$\begin{array}{c}\text { Human } \\
\text { activities }\end{array}$} & $\begin{array}{l}\text { Abrasion } \\
\text { knowledge }\end{array}$ & $\begin{array}{c}\text { Community } \\
\text { knowledge about } \\
\text { understanding, } \\
\text { causes, effects, and } \\
\text { mitigation of } \\
\text { abrasion }\end{array}$ & $\begin{array}{l}\text { Questionnaire } \\
\text { and Interview }\end{array}$ \\
\hline & $\begin{array}{l}\text { Attitude } \\
\text { towards } \\
\text { abrasion }\end{array}$ & $\begin{array}{l}\text { Types of activities } \\
\text { carried out by the } \\
\text { community, the } \\
\text { community with } \\
\text { the community, the } \\
\text { government, or the } \\
\text { community with } \\
\text { the government to } \\
\text { prevent and } \\
\text { overcome } \\
\text { abrasion. }\end{array}$ & $\begin{array}{l}\text { Questionnaire } \\
\text { and Interview }\end{array}$ \\
\hline & $\begin{array}{l}\text { Abrasion } \\
\text { mitigation }\end{array}$ & $\begin{array}{l}\text { Activities carried } \\
\text { out by the } \\
\text { community to } \\
\text { prevent and } \\
\text { overcome abrasion } \\
\text { at the research site. }\end{array}$ & $\begin{array}{c}\text { Interview and } \\
\text { Observation }\end{array}$ \\
\hline
\end{tabular}

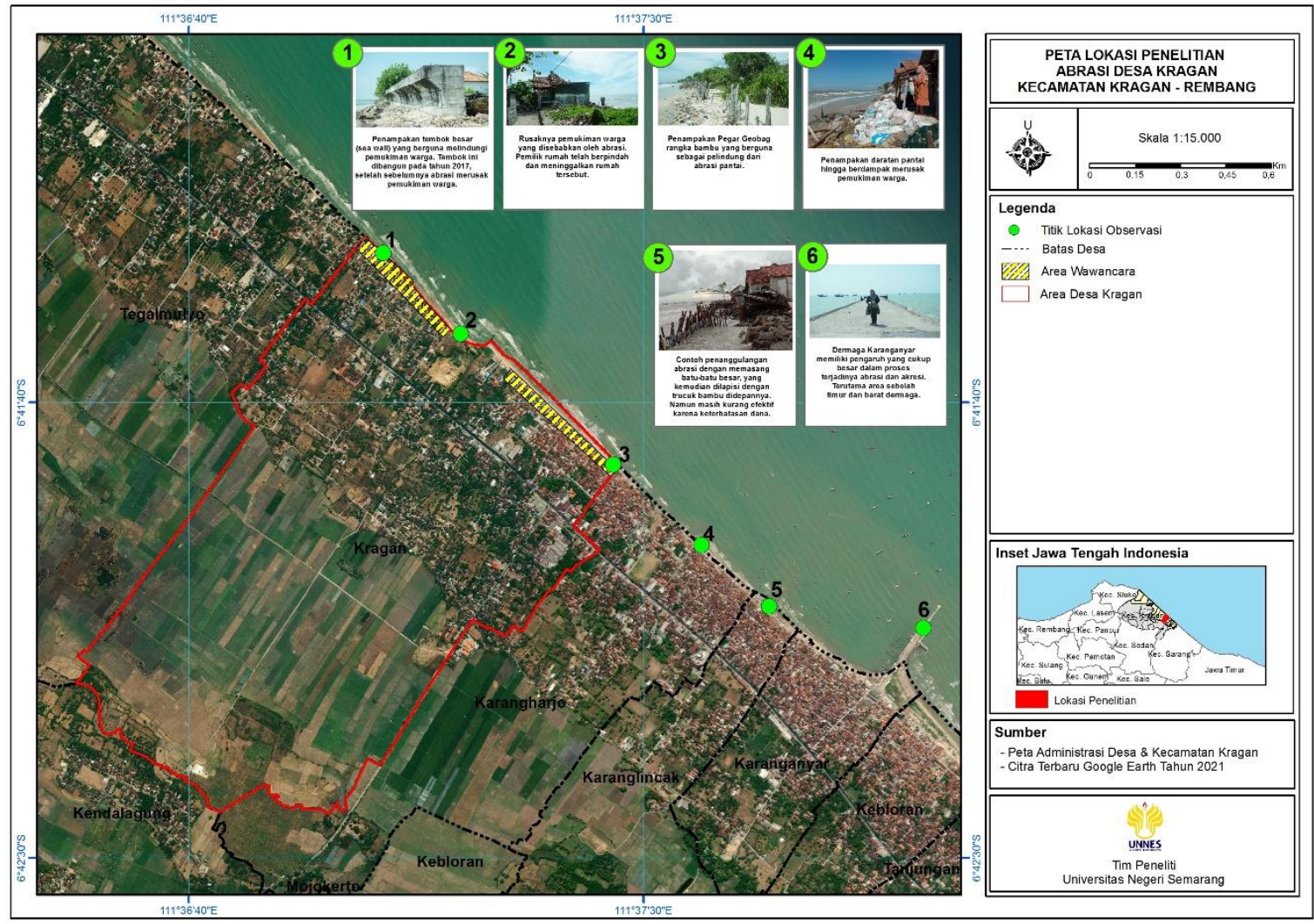

Figure 2. Abrasion research locations in Kragan Village 
The questionnaire used to measure the community's knowledge and attitudes was compiled based on several indicators, as shown in Table 2. These indicators refer to research by by Hamid [13], Annisa \& Setyowati [37], and Juhadi et al. [38].

Table 2. Indicators of community's knowledge and attitudes capacity

\begin{tabular}{|c|c|c|}
\hline Indicators & $\begin{array}{c}\text { Item } \\
\text { Number }\end{array}$ & $\begin{array}{l}\text { Total } \\
\text { items }\end{array}$ \\
\hline \multicolumn{3}{|c|}{ Knowledge of Abrasion } \\
\hline Definition of abrasion & 1 & 1 \\
\hline $\begin{array}{l}\text { Trigger factors that directly cause } \\
\text { abrasion }\end{array}$ & 2 & 1 \\
\hline $\begin{array}{l}\text { Control factor that indirectly causes } \\
\text { abrasion }\end{array}$ & 3,8 & 2 \\
\hline $\begin{array}{c}\text { Abrasion characteristics that occur in } \\
\text { Kragan Village's coastal }\end{array}$ & $\begin{array}{l}4,5,6 \\
\text { dan } 10\end{array}$ & 4 \\
\hline Impact due to abrasion & 7 & 1 \\
\hline Abrasion prevention/mitigation & 9 dan 11 & 2 \\
\hline $\begin{array}{l}\text { Environmental physical susceptibility } \\
\text { to abrasion }\end{array}$ & $\begin{array}{l}12,13,14 \\
\text { dan } 15\end{array}$ & 4 \\
\hline \multicolumn{3}{|c|}{ Attitude in dealing with abrasion } \\
\hline Attitude before abrasion & 1 dan 2 & 2 \\
\hline Attitude during and after abrasion & 3 & 1 \\
\hline
\end{tabular}

The population in this quantitative study is all the heads of families in Kragan Village, totaling 1581. The sample is Kragan Village residents who are directly affected by abrasion, as many as 147 people. We took a random sample of $20 \%$ of the total residents of Kragan Village who were directly affected by abrasion.

Quantitative data analysis techniques were carried out using quantitative-qualitative descriptive analysis techniques. Quantitative data on the knowledge and attitude questionnaire of the community towards abrasion was calculated so that it was known that the knowledge and attitudes of the community towards abrasion were scored on each item and each indicator. After knowing the score of each indicator, then the score is compared with the ideal score and then multiplied by $100 \%$ so that the percentage of the final capacity of knowledge and attitudes of the community and the capacity of each indicator is obtained. The intervals for each aspect are shown in Table 3 below.

Table 3. Community capacity category score on each aspect

\begin{tabular}{cc}
\hline Interval Skor (\%) & Kategori \\
\hline $75-100$ & Very Good \\
$50-75$ & Good \\
$25-50$ & Enough \\
$1-25$ & Less \\
\hline & Source: [39]
\end{tabular}

The percentage obtained is then converted into the category of community capacity. The community capacity questionnaire in this study consisted of 18 question items, the maximum score for community capacity was 90 , and the minimum score was 18 . The score was used to find the width of the interval that would be used as a basis for determining the category of community capacity. The width of the interval is found using the following formula.

$$
i=\frac{\text { Measurement Distance }(\mathrm{R})}{\text { Number of intervals }}[39]
$$

\section{Keterangan}

$i=$ Number of intervals

$\mathrm{R}=$ Measurement Distance $=$ Highest score - Lowest score

Based on the calculation using this formula with a total of 4 intervals, it is known that the value of $i$ in individual capacity is 18 . Therefore, the individual capacity categories can be broken down based on the scores obtained with the score intervals shown in Table 4.

Table 4. Community capacity category

\begin{tabular}{cc}
\hline Score Interval & Category \\
\hline $72-90$ & Very Good \\
$54-72$ & Good \\
$36-54$ & Enough \\
$18-36$ & Less \\
\hline \multicolumn{2}{c}{ Source: [39] }
\end{tabular}

The validity of the qualitative data in this study is known through the triangulation of techniques and research data sources. The results of this quantitative study were then reviewed based on the results of observations and interviews on activities carried out by the community daily. Technical triangulation is carried out through interviews with research subjects, while source triangulation is carried out on people who are not research subjects. Activities carried out by the community on the coast will significantly affect the occurrence of abrasion, where these activities are strongly influenced by the knowledge and attitudes of the community towards abrasion. The qualitative data analysis was carried out both before, while in, and after from the field. The data obtained before going to the field is reviewed while in the field, then the data obtained when in the field is re-sorted so that only data that is in accordance with the research objectives will be used.

\section{RESULTS AND DISCUSSION}

\subsection{Coastal changes due to abrasion 2003-2020}

Rembang Regency is one of the regencies in Central Java Province. Rembang Regency is traversed by the Java North Coast Road (Pantura Road). Rembang Regency is located at coordinates $111^{\circ} 00^{\prime}-111^{\circ} 30^{\prime}$ East Longitude and $06^{\circ} 30^{\prime}$ $07^{\circ} 60^{\prime}$ South Latitude. The administrative boundaries of Rembang Regency are in the north by the Java Sea, in the south by Blora Regency, in the west by Pati Regency, and in the east by Tuban Regency. The mainland in Rembang Regency is a lowland morphology that widens in the Juwana area and narrows towards Tayu and Rembang, as well as a mountainous morphology that only occupies part of the eastern slope of Mount Muria [40]. The seabed morphology is sloping in a northwest-southeast direction, gradually becoming relatively flat to the northeast. Small coral reefs and volcanic rocks appear in the eastern part of the beachfront [41].

Furthermore, the coastal area of Rembang Regency is a bay area located in the northern coastal area of Java Island and belongs to the category of open water. The wave energy towards the coast is exceptionally influential on the dynamics of the coastal process. Seabed surface sediments in the coastal area of Rembang Regency are supplied from land sediments through rivers and from rocks around the coast due to abrasion 
of sea waves, causing acceleration along the coast. The geomorphology of the coastal area of Rembang Regency consists of 4 (four) units, namely: the morphology of the alluvium plain, the morphology of the lowlands, the morphology of the highlands, and the morphology of the hills. The process of sedimentation around river estuaries forms acceleration along the coast of Rembang Regency. The dominant longshore current is from east to west, and this is indicated by the direction of the spit that leads to the west like sandbar along the Dasun area to Tireman [42].

Kragan Village is directly adjacent to the Java Sea in the north, making this village prone to abrasion. Several areas on the coast of Kragan Village have experienced abrasion, and several other areas can experience abrasion in the future. Abrasion causes the length of the coastline of Kragan Village to change, namely to experience a decline. Measured in 2021, the coastline of Kragan Village is 1.28 kilometers, as shown in Figure 3.

Based on the Landsat-5TM image, before 2003, the condition of the Kragan beach was seen with white sand, which indicated that the distance from the sea to the settlement was still far and had not been affected by abrasion. However, from 2003 to 2020, abrasion dynamics occurred at specific locations, resulting in changes in the coastline from year to year, as shown in Figure 4.

This study observed three sample points, all of which were taken on the coast of Kragan Village. In the first sample point, before 2003, the site had a large coastal area. However, in 2003 and 2004, an abrasion damaged settlements and harmed the community because seawater entered the residents' houses approximately 10 meters from the shoreline. In addition, in 2004 there was an abrasion with the most significant total loss, which reached more than 900 million rupiahs. Furthermore, in 2010, the community built a small port in Karanganyar Village, so that Kragan Village was affected by 8 meters of abrasion for a period of 6 years, starting from 2010 to 2015. Until 2015, efforts were made to overcome it by building an abrasion retaining wall for the community's cooperation with students from several universities and the private sector. However, the construction of the wall has not given much meaning because the abrasion at this point will continue until 2020. Sample point 1 is shown in Figure 5.

At the 2nd sample point, coastal dynamics began to occur in 2004. A total of 64 boats owned by fishermen and stalls built around the coast were damaged due to being hit by abrasion. This point was also affected by the construction of a small port in Karanganyar Village, as was the first point, so that at this point, an abrasion retaining wall was also built-in 2015. As with point 1 , abrasion at this point will also continue until 2020 Every year this point experienced a land reduction of between 0.5 and 3 meters, with the peak of the most considerable land reduction in 2020 with a reduction of 8 meters. Sample point 2 is shown in Figure 6.

As for the 3rd sample point, beach dynamics also began to occur in 2003. Abrasion in 2003 caused damage to residents' houses with a total loss of 73 million. Meanwhile, in 2004, as many as 60 fishing boats were damaged. Abrasion also occurs continuously throughout the year, except in 2005 to 2009 , which did not experience abrasion. Sample point 3 is shown in Figure 7.

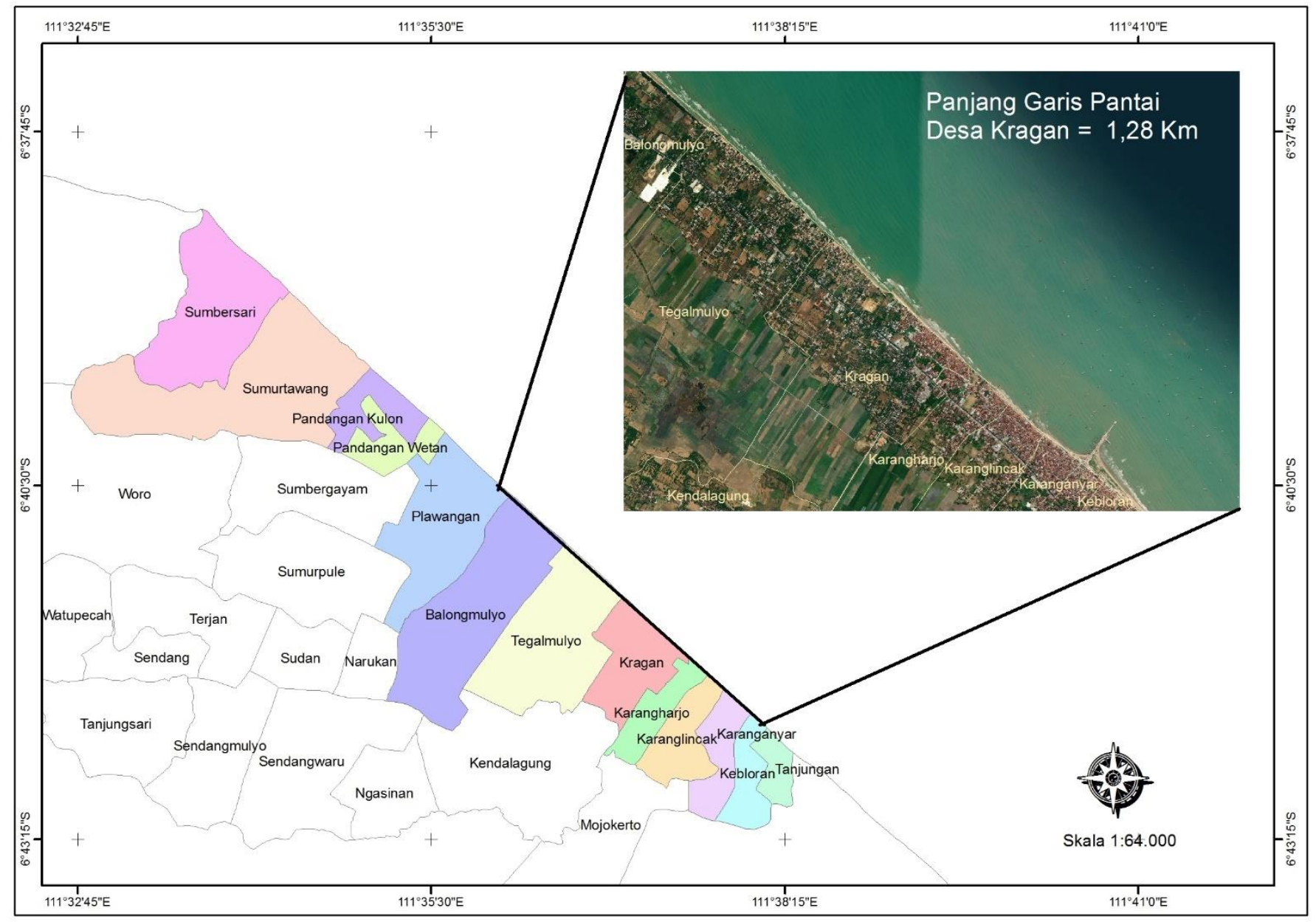

Figure 3. The length of the coastline of the Kragan-Rembang area 


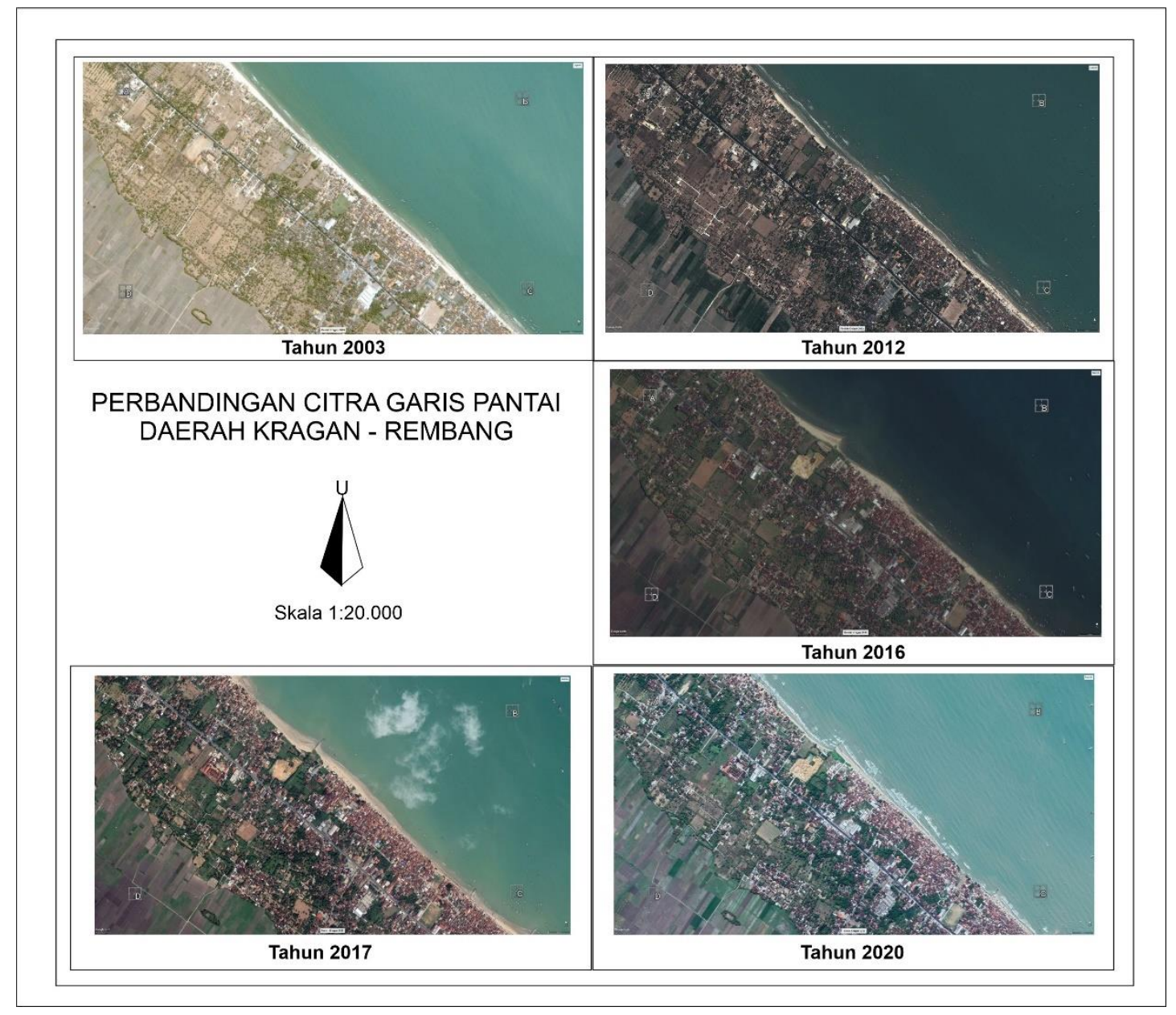

Figure 4. Comparison of Kragan village coastline image

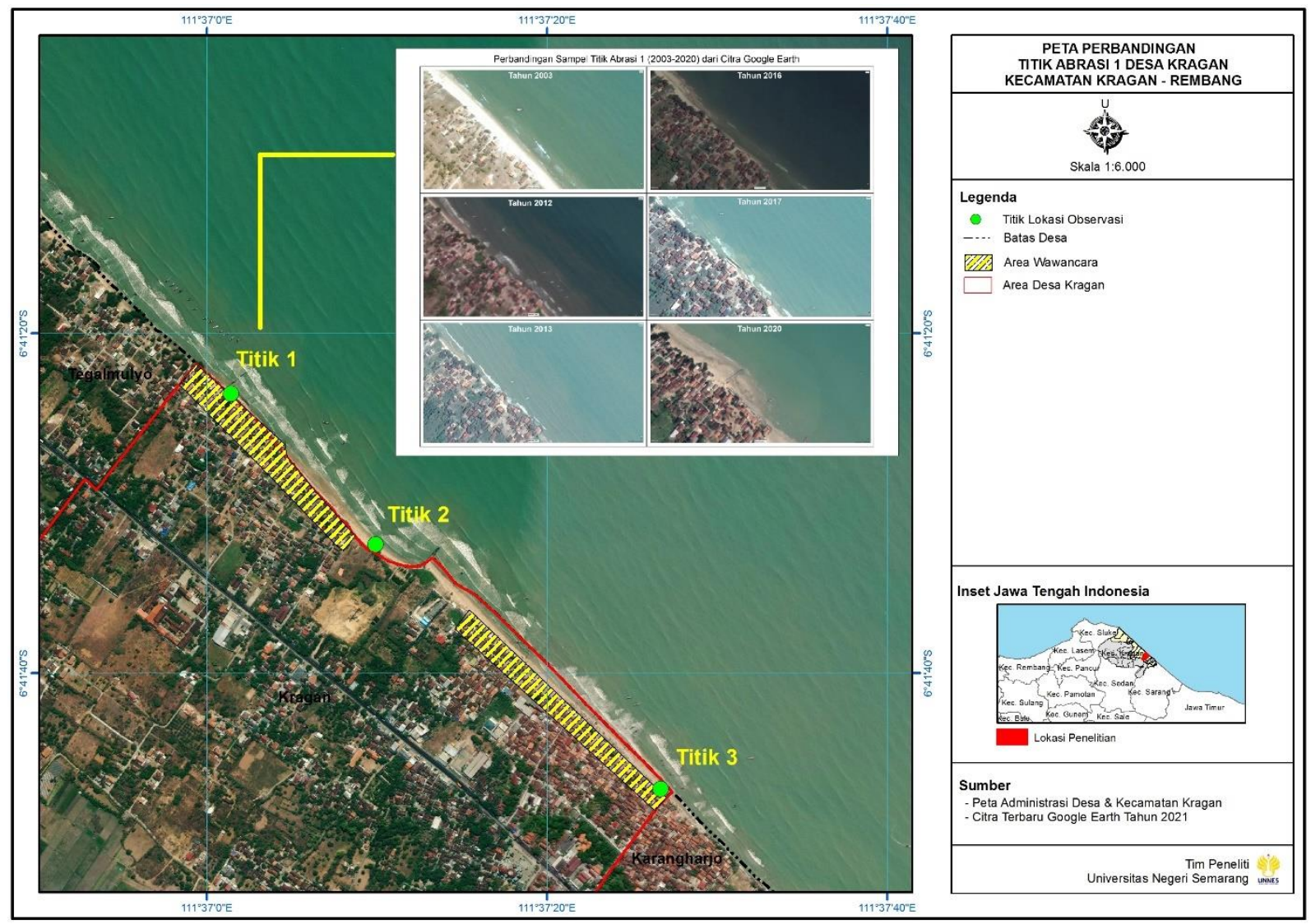

Figure 5. Abrasion sample point 1 


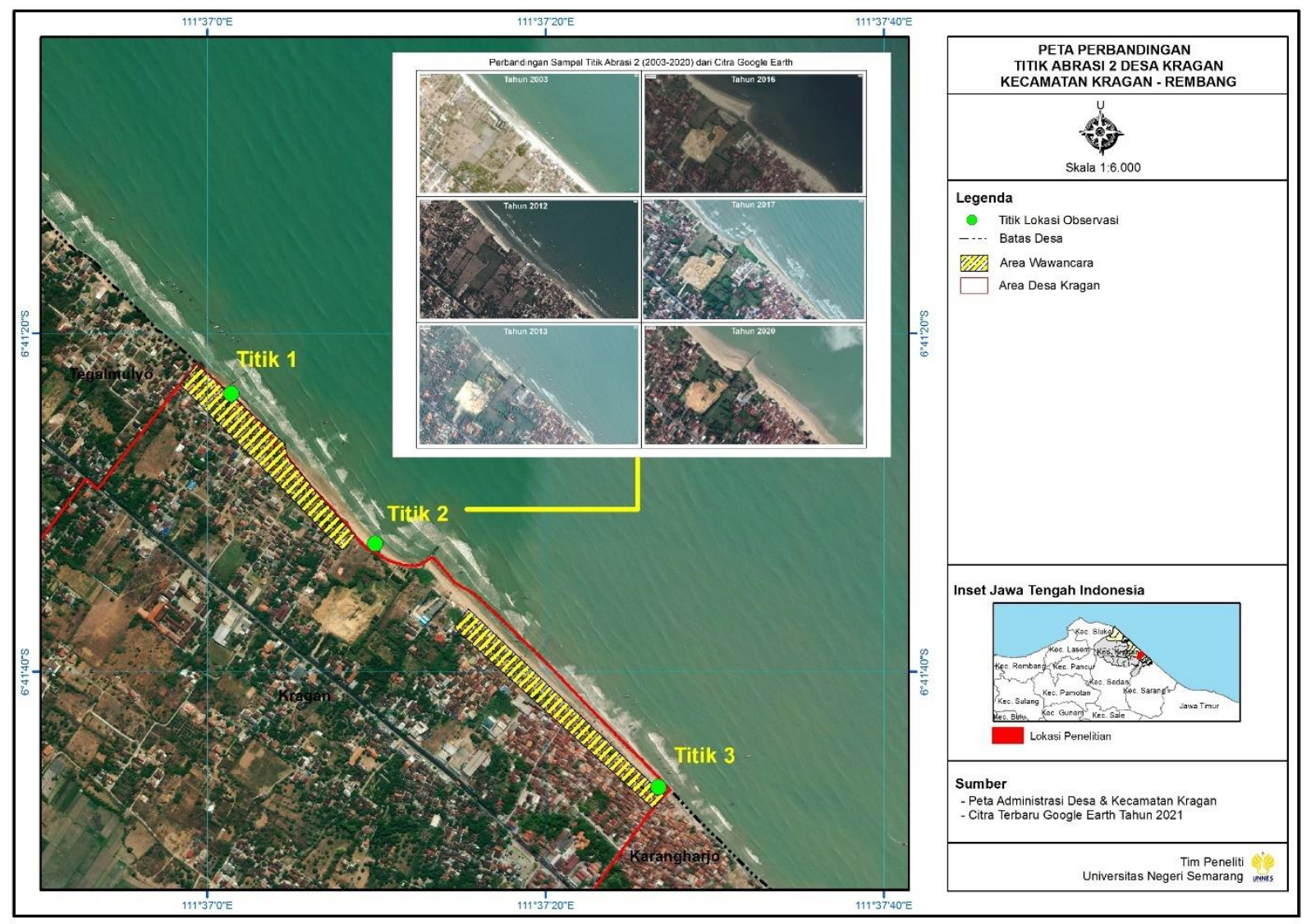

Figure 6. Abrasion sample point 2

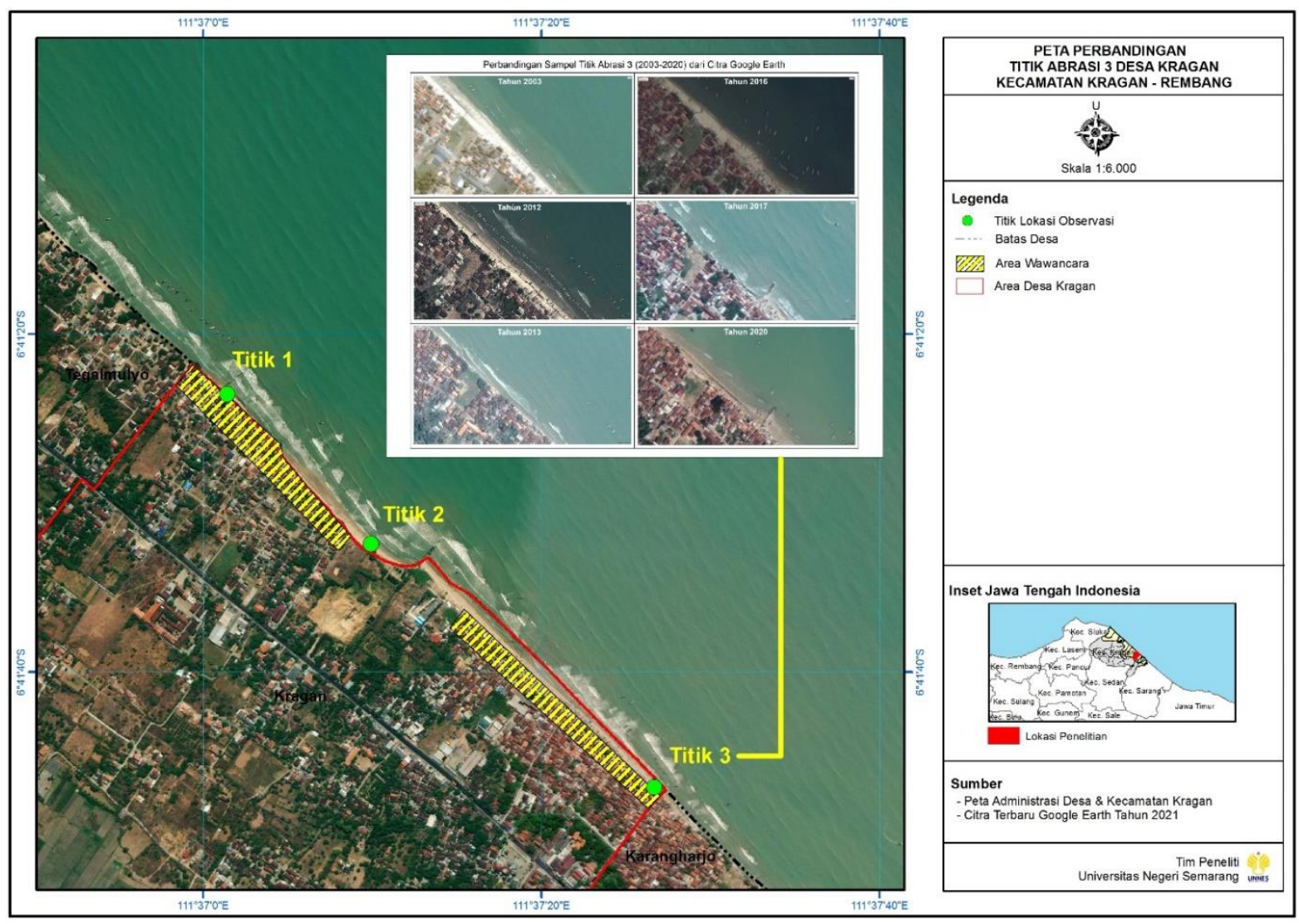

Figure 7. Abrasion sample points 3

Research on coastal dynamics carried out in this study was complemented by measuring the loss of land in the Kragan Village Coast at the three observation points due to abrasion.
The loss data from the three points are averaged, so it is known that the average land loss in Kragan Village from 2003 to 2020 is shown in Figure 8 below. 
Graph of Land Loss in Kragan Village in 2003-2020

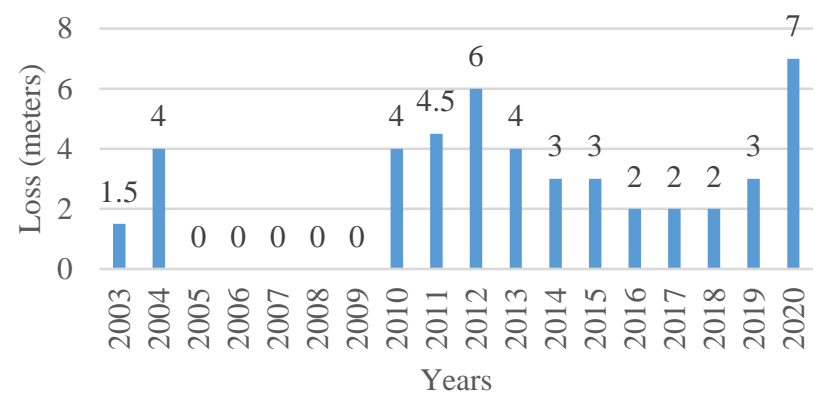

Figure 8. Loss of land on the coast of Kragan village due to abrasion in 2003-2020

Based on Figure 8, it is known that almost every year, there is always abrasion on the coast of Kragan Village. From 2003 to 2020 , there was always a reduction in land due to abrasion, except from 2005 to 2009 . In that year, the mangrove forest was not widely used by the community to build ponds. Previously, around 2000 mangroves had been planted so that in 2005 the mangroves were able to withstand abrasion. Until 2009, mangroves continued to support coastal life by resisting incoming abrasion waves so that there was no land reduction due to abrasion during that period. This result is supported by Feka and Ajonina which state that mangroves play a significant role in defending coastal areas from the danger of abrasion. Meanwhile, if the mangroves continue to be cut down, the mangroves will be in a critical condition due to reduced cover, so that the mangroves will not be able to carry out their function as an anti-abrasion [43, 44].

Meanwhile, since 2010, the community has started to carry out activities that trigger significant abrasion. People cut mangroves to use them as building materials and fuel. The community then uses the former mangrove forest as ponds, fish ponds, and salt ponds, so there is no longer a mangrove root system that can stabilize and shape the soil by increasing sediment accretion [45]. In addition, the community also built a small port in Karanganyar Village. This port is helpful as a shelter for fishing boats that will dock and as the most prominent fish auction place in Kragan District. However, the waves towards the mainland were diverted to the east and west, assisted by the speed of the sea wind, so that the big waves headed eastward to Tanjungan Village and west towards Kragan Village. The loss of the coastal barrier in mangroves and the construction of a small port made Kragan Village hit by abrasion consecutively from 2010 to 2020 . During this time, at least 40.5 meters of land in Kragan Village were eroded by abrasion, with an average loss per year is 3.68 meters. If calculated since 2003, the total land lost is 46 meters with an annual average of 3.54. Cialdea [46] stated that the Urban Beach Plan also experienced an extraordinary abrasion phenomenon due to the construction of the Termoli Port. This result is also supported by the research of Mohammed et al. [47], which states that human activities significantly affect the rate of soil erosion (or, in this study is abrasion).

Abrasion that occurred in Kragan Village has resulted in beach dynamics. The coastline continues to decline due to abrasion. Abrasion also results in the fall of trees, damage to ships, loss of various fishing equipment, and damage to people's homes and public facilities. One of the portraits is the damaged road in Kragan Village, shown in Figure 9 as follows.

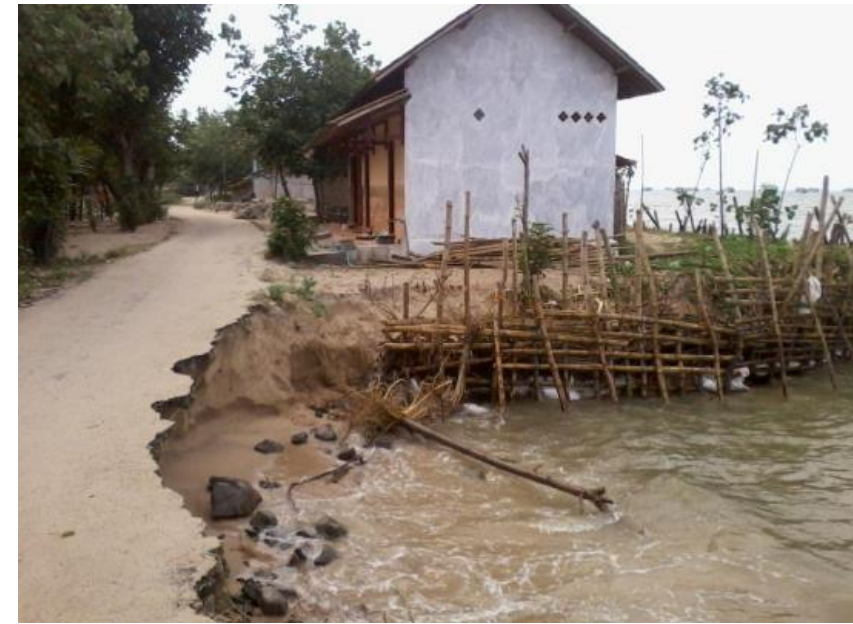

Figure 9. Road damage in Kragan village due to abrasion

\subsection{Human activities that cause coastal dynamics}

There are several lands uses and human activities along the coast of Rembang Regency which have a significant impact on the dynamics of the coast. The land uses are constructing fishing boat ports, making milkfish and salt ponds, and fish processing places. The community also cut down mangroves, and other vegetation on the coast, carried out sand mining, and destroyed coral reefs. In addition, people from outside Kragan Village also mine sand and destroy coral reefs irresponsibly. These activities are considered to have triggered the occurrence of abrasion in Kragan Village. This is because abrasion is generally caused by the loss of the natural carrying capacity of the coast, such as mangroves [5]. The community replaces the mangrove forest by opening aquaculture, where these activities significantly trigger the occurrence of abrasion. Some pond lands have even been abandoned by the cultivators so that seawater inundates the pond area and erodes the pond's shores (pond embankment). These community activities trigger abrasion, which in the end will also lead to coastal dynamics $[12,27]$.

The existence of activities that trigger the occurrence of abrasion is because the community does not yet have comprehensive knowledge about abrasion. Some communities own accurate and comprehensive knowledge, but this community cannot prohibit other interested communities because it is related to the role of various political interests which are more concerned with the interests of groups and individuals than the sustainability of nature and its resources, till carrying out destructive activities [48]. People who know about abrasion as a whole are those who have attended socialization or taken education. As for the rest of the community, their knowledge is only limited to experiences that have been experienced while living in the area and then provide their conclusions based on personal thoughts or opinions. Through education in schools, students are taught about disaster education and environmental education, so that students have geographical skills, one of them is in dealing with disasters [49].

Only a few people's thoughts form the knowledge about abrasion that is understood by the community. Among the right thoughts are about the causes of abrasion caused by waves, currents, and strong winds. However, as many as $54 \%$ of the people do not know about the factors that cause abrasion directly, and $47 \%$ do not know about the factors that indirectly cause abrasion. Another appropriate thought is about the 
characteristics of abrasion that occurred in Kragan Village, where $61 \%$ of the community has understood it. However, as many as $41 \%$ of the community do not understand areas where abrasion has not yet occurred, but those areas have the potential for abrasion in the future. In addition, the community also has a good understanding of the impact of abrasion with a percentage of $51 \%$ because the community has experienced and witnessed the incident for themselves. Some people who do not understand have just lived or moved houses to the village, so they have not experienced or seen abrasion directly.

Other knowledge indicators that are still poorly understood by the community include the public's understanding that an abrasion is a natural event and an annual event that naturally occurs. As many as $57 \%$ of the people have misconceptions about the meaning of abrasion. People do not understand that abrasion is also an event that can be caused by human behavior that damages coastal areas. This misunderstanding has implications for knowledge about preparedness actions that are less precise and comprehensive so that as many as $50 \%$ of the community do not understand preparedness actions in dealing with abrasion appropriately. The aspect that is least understood by the community is about the physical vulnerability of the environment to abrasion. People do not know that an area's vulnerability to abrasion is not only determined by current and wave height factors. However, it is also determined by coastal physical factors such as beach typology, vegetation cover, and shoreline shape [2]. Indicators of community's knowledge in more detail are shown in Figure 10.

The second aspect examined in this study to determine community activities is the attitude in dealing with abrasion. The attitudes identified in this study are attitudes before, during, and after the disaster [50]. Attitude before the occurrence of abrasion can be categorized as low. Based on the questionnaire results, it is known that among the abrasion prevention actions that the community should carry out, only $35 \%$ have been carried out; in this case, the community has carried out mutual cooperation to lay large stones build walls that prevent abrasion. Meanwhile, $65 \%$ of abrasion prevention measures, such as planting vegetation, constructing buildings far from the coast, and using the Climate Information System, have not been carried out. Various actions taken by the community in the period 2003 to 2020 were actions that triggered abrasion, such as cutting down mangroves and converting them into shrimp ponds, destroying coral reefs, and taking various actions that trigger climate change. Climate change can ultimately increase sea levels, thus triggering abrasion and coastline decline [51].

Attitudes with a high percentage in this study are attitudes during and after abrasion, 54\%. When abrasion occurs, the community works hand in hand to help other communities, especially those with high vulnerabilities, such as the elderly, sick people, and children. People tried to pick them up and rescue them to a safer location. In addition, the community also has an attitude of disaster preparedness, so that people try to run fast and save themselves when sudden abrasion occurs. As for after the abrasion, the community's attitude is shown by the existence of a culture of "gotong royong" or helping each other in carrying out rehabilitation efforts. People who experience damage to their homes will be assisted in rebuilding their houses as before. Homeowners only need to prepare the materials needed; then, the community will help with labor for free. In addition, the community also jointly repairs damaged public facilities. Indicators of the community's attitudes in dealing with abrasion in more detail are shown in Figure 11.

Based on the data on the capacity of knowledge and attitudes that have been obtained, it can be seen that, in general, the capacity of the community in dealing with abrasion is still in the sufficient category. The result is shown in Table 5.

As for mitigation efforts, the people of Kragan Village have implemented several forms of structural mitigation efforts, as shown in Figure 12. The community's form of structural mitigation is more inclined to the mechanical method than the vegetation method, among the mitigation efforts, namely by arranging large rocks around the house and on the shoreline and building abrasion retaining walls. However, the vegetation method carried out by planting mangroves, and other vegetation was not carried out. The community converts the mangrove forest into fishponds.

Community's Knowledge about Abrasion

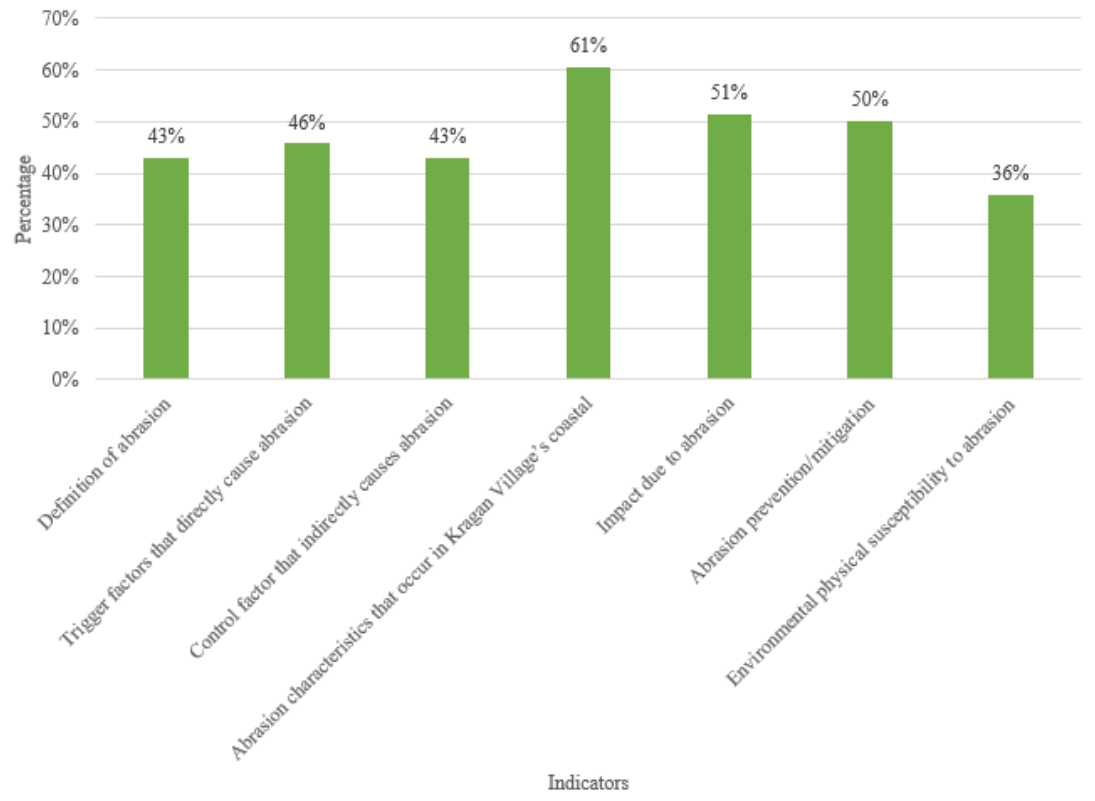

Figure 10. Community's knowledge-based on indicator 
Community's Attitudes

in Dealing with Abrasion

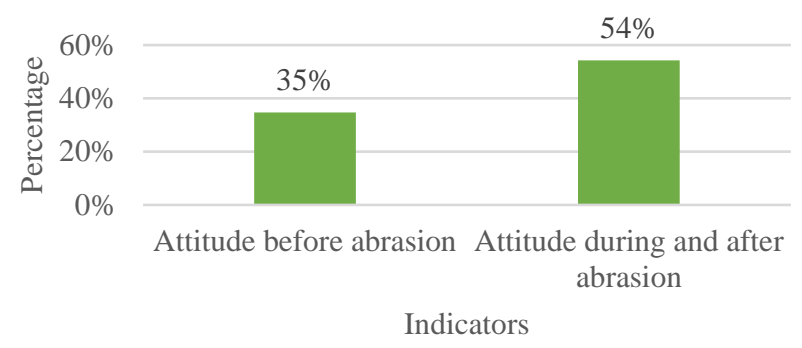

Figure 11. Community's attitudes based on indicator

Table 5. Category of Kragan village community capacity (knowledge and attitude) in facing disaster

\begin{tabular}{ccc}
\hline Aspects & Ideal Score & Average Score \\
\hline Knowledge & 75 & 35.54 \\
Attitude & 15 & 6.18 \\
Total Average Score & 41.72 \\
Community Capacity's Category & Enough \\
\hline
\end{tabular}

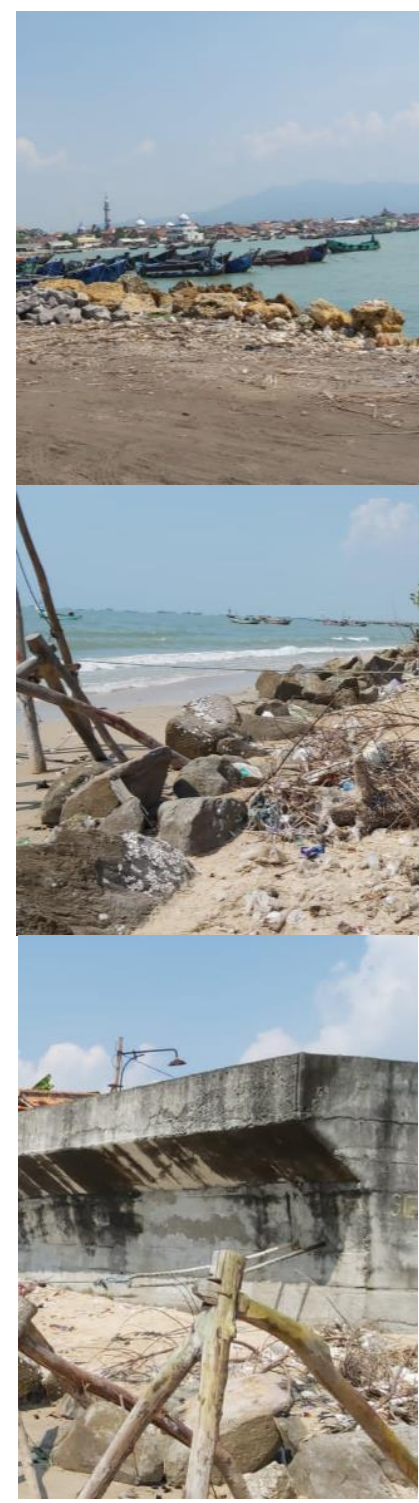

Figure 12. Structural mitigation performed by the community
In addition to structural mitigation, the community also has local wisdom. The people of Kragan Village, on average, have occupied their current place of residence for decades. During that time, various disasters have occurred and were able to be faced by the community because the community has local wisdom. Based on the interview results, it can be seen that the community has local wisdom in the form of "Sambatan," where the community works together and works for hand in hand to create an environment that is safe from abrasion. Splice, in this case, is social capital which is one of the community's capacities to reduce the impact of abrasion [52].

As for non-structural mitigation, it is known that the community has not implemented it optimally. The community has never received disaster education or special preparedness training on abrasion. Based on the interviews conducted, it is also known that the community has not provided disaster education to children and their families independently. Disaster education is an essential component that must be obtained by the community, especially those living in disasterprone areas [53]. Disaster education can increase knowledge, attitudes, preparedness, and participation in dealing with disasters $[16,54]$.

Given that the community has not received maximum disaster education, it is not surprising that the community's knowledge about abrasion is still low so that people take actions that are natural according to the community's perception. However, these actions trigger abrasion. Knowledge and perception impact the actions are taken [5557].

\subsection{Human activities towards coastal areas sustainable management}

The protection of coastal areas in order to remain sustainable can no longer be postponed. Among the things that can be done are natural adaptations, for example, planting mangroves, maintaining coral reefs, not mining for sand, and carrying out structural mitigation $[22,58]$. Even so, people with various levels of education in Kragan Village do not all understand effective abrasion prevention, so there must be an effort from the government to provide socialization and training [59]. Knowledge of coastal areas and their management must also be provided, considering that this knowledge is the basis for wise and sustainable management [22]. Another important thing is that the government must also provide clear and consistent instructions regarding abrasion prevention, which is manifested in legislation. In addition, development planning and implementation should also accommodate information submitted by communities directly dealing with abrasion so that the principle of 'top down' development can be changed to 'bottom-up' [60].

The coastal management must be carried out collaboratively between various parties, including the local community and the government [61]. First, society is the main subject. Coastal communities are components that occupy coastal areas so that they will be the ones who will be faced directly with various disasters, and they are also the ones who feel the impact if a natural disaster occurs. Therefore, the community must play a significant role in preserving coastal areas from internal and external threats. Tobey et al. [22] said that the community could involve the government and other institutions that focus on coastal management, such as universities, and ask for consideration from policymakers to provide opinions and choose leaders. Second, the government. The government, in 
this case, does not only give orders or advice but also participates in inclusive collaboration by sending representatives. In this case, the government becomes a facilitator who supports participatory democracy. The government's role, in this case, is to coordinate, facilitate, and support. The role of the community is inclusive, equitable, and effective decision-making [60]. Collaborative governance in environmental management can be done through dialogue, transparency to the public, monitoring, follow-up by governance, and actions [62].

Sustainable coastal management in Kragan Village is disrupted due to harmful human activities that are detrimental. These human activities are carried out by the people of Kragan Village and are also carried out by people outside the Kragan Village. Among the activities of the community outside Kragan Village is mining for sand. The implementation of the plans that have been prepared to produce a more sustainable coastal environment is disrupted by these activities. For example, when the local community has committed to reducing the abrasion disaster, people outside Kragan Village mine sand irresponsibly. As a result, residents became angry, and there were clashes between residents and foreigners, one of which happened in 2018 in the Kragan District area. These harmful human activities can ultimately interfere with the implementation of sustainable coastal management programs that are starting to be implemented.

Harmful human activities can disrupt the basic principles of integrated coastal management $[63,64]$. The first principle that is disturbed is the principle of sustainability, where due to excessive dredging of coastal resources will threaten the availability of these resource stocks in the future so that the principle of sustainability will be hampered. The second principle is equity, where if certain parties exploit the coast, then only those parties who enjoy the results from the coast, while other communities do not enjoy it so that the principle of equity cannot be achieved. The third principle is the principle of integration, where when one of the people, institutions, or government commits an act that violates, the principle of integration between stakeholders cannot be appropriately achieved [31].

Processes in the management of coastal areas are also disrupted due to human activities that damage coastal resources. Supposedly, if various coastal utilization activities are carried out, such as sand mining or land use as a pond area, a permit process is required. However, in the Rembang Regency in general and Kragan Village in particular, various activities of using coastal resources illegally or without a permit process were found. As a result, actors will use resources according to their own wishes, regardless of natural resources' carrying and regeneration capacity. As a result, the use of natural resources is not in accordance with the established plans, and stakeholders are also unable to control the existence of these natural resources. As a result, future coastal management will experience obstacles $[31,65]$.

\section{CONCLUSIONS}

The beaches in Kragan Village at the three points observed have all experienced dynamics. This is indicated by the decrease in land area from 2003 to 2020, with a total land loss of 46 meters with an average annual loss of 3.54. The community carries out the human activities that trigger the occurrence of abrasion from outside and within the Kragan village, including illegal logging of mangroves to be used as fuel and building materials and the conversion of their land as ponds, construction of buildings jutting into the sea, coral reef destruction and sand mining. Harmful activities carried out by the community resulted in abrasion so that the coast experienced dynamics. Human activities also affect coastal management, namely the basic principles of integrated coastal management and processes in the management of coastal areas. One of the reasons for this activity was the low knowledge and attitude of the community in dealing with abrasion. If this activity continues, the coast of Kragan Village may become unsustainable. Therefore, efforts should be made to improve integrated coastal management

\section{ACKNOWLEDGMENT}

We want to thank Semarang State University for providing financial assistance so that this research can be carried out correctly.

\section{REFERENCES}

[1] Amri, M.R., Yulianti, G., Yunus, R., Wiguna, S., Adi, A.W., Ichwana, A.N., Randongkir, R.E., Septian, R.T. (2016). Indonesian Disaster Risk. Jakarta: National Board for Disaster Management. https://inarisk.bnpb.go.id/pdf/Buku\%20RBI_Final low. pdf.

[2] Abda, M.K. (2019). Disaster Mitigation against coastal abrasion in Kuala Leuge, East Aceh District. J. Samudra Geogr., 2(1): 2-5. https://ejurnalunsam.id/index.php/jsg/article/view/1802.

[3] Pratikto, W.A., Haryo, D.A., Suntoyo, S. (2007). Beach and Marine Facility Planning (in Indonesian). Yogyakarta: BPFE-Yogyakarta. https://opac.perpusnas.go.id/DetailOpac.aspx?id=15709 4.

[4] Diposaptono, S. (2011). A Collection of Thoughts: Disaster Mitigation and Climate Change Adaptation. Jakarta: Direktorat Pesisir dan Lautan Direktorat Jenderal Kelautan, Pesisir dan Pulau-pulau Kecil Kementerian Kelautan dan Perikanan. https://kkp.go.id/an-component/media/upload-gambarpendukung/DitJaskel/sbdn/Mitigasi\%20Bencana\%20da n\%20Adaptasi\%20Perubahan\%20Iklim.pdf.

[5] Mulyadi, A., Efriyeldi, Hamidy, R., Nofrizal. (2021). Development of mangrove ecotourism in Bandar Bakau Dumai based on disaster mitigation. International Journal of Sustainable Development and Planning, 16(7): 13591367. https://doi.org/10.18280/ijsdp.160716

[6] Marfai, M.A. (2008). Coastal hazard assessment and management in Semarang City, Indonesia: The case study of enhanced tidal inundation due to land subsidence and scenario of sea level rise (Doctoral dissertation).

[7] Mangroves for the Future (MFF). (2015). National Strategy and Action Plan: Indonesia 2012-2015. https://www.mangrovesforthefuture.org/assets/Reposito ry/Documents/MFF-Indonesia-NSAP-2012.

[8] Bagli, S., Soille, P. (2003). Morphological automatic extraction of Pan-European coastline from Landsat ETM+ images. In International symposium on GIS and 
Computer Cartography for Coastal Zone Management, 256-269.

[9] Mills, J.P., Buckley, S.J., Mitchell, H.L., Clarke, P.J., Edwards, S.J. (2005). A geomatics data integration technique for coastal change monitoring. Earth Surface Processes and Landforms: The Journal of the British Geomorphological Research Group, 30(6): 651-664. https://doi.org/10.1002/esp.1165

[10] Sunarto, S. (2004). Geomorphic Changes in Coastal Area Surround Muria Volcano (in Indonesian). Gadjah Mada University Yogyakarta. https://repository.ugm.ac.id/65096/.

[11] Pinto, Z. (2016). Study of coastal community behavior that causes environmental damage (Case study at Kuwaru Beach, Poncosari Village, Srandakan District, Bantul Regency, DIY Province) (in Indonesian). J. Wil. dan Lingkung., $\quad 3(3)$ : 163 https://doi.org/10.14710/jwl.3.3.163-174

[12] Trihatmoko, E., Pratiwi, E.S., Sanjoto, T.B., Marfai, M.A. (2021). A numerical study of tidal run up and inundation impact using logical tool-less than equal. In IOP Conference Series: Earth and Environmental Science, 683(1): $\quad 012062 . \quad$ https://doi.org/10.1088/1755$1315 / 683 / 1 / 012062$

[13] Hamid, N. (2018). Study of community capacity in dealing with the threat of shore erosion in Kragan Subdistrict Rembang district. Pancaran Pendidikan, 7(3): 57-70. https://doi.org/10.25037/pancaran.v7i3.193

[14] Setyowati, D.L., Hardati, P., Benardi, A.I., Hamid, N., Anugrahanto, Y.D. (2021). The role of the disaster preparedness group in adapting abrasion to communities affected by abrasion on the North Coast of Rembang, Central Java. Int. Conf. Educ. Soc. Sci. (ICESS 2021), 578: 61-66. https://www.atlantispress.com/proceedings/icess-21/125961160.

[15] Hossain, M.S., Gain, A.K., Rogers, K.G. (2020). Sustainable coastal social-ecological systems: how do we define "coastal"? International Journal of Sustainable Development \& World Ecology, 27(7): 577-582. https://doi.org/10.1080/13504509.2020.1789775

[16] Takeuchi, Y., Mulyasari, F., Chapter, R.S. (2015). Chapter 4 roles of family and community in disaster education. Disaster Education, 7: 77-94. http://dx.doi.org/10.1108/S2040 7262(2011)0000007010

[17] Juhadi, J., Banowati, E., Sanjoto, T.B., Nugraha, S.B. (2020). Rapid appraisal for agricultural land utilization in the erosion and landslide vulnerable mountainous areas of Kulonprogo Regency, Indonesia. Manag. Environ. Qual. An Int. J., 31(1): 1-17. http://doi.org/10.1108/MEQ-01-2019-0023

[18] Shaw, R., Scheyvens, H., Prabhakar, S.V.R.K., Endo, I. (2016). Disaster risk reduction for sustainable development. IGES Natural Resources and Ecosystem Services

Area. https://pub.iges.or.jp/pub file/drrpdf/download.

[19] Maulana, I., Hayati, R. (2019). The use of multitemporal satellite imagery media in learning in Tanggultlare village communities regarding abrasion in 2018 (in Indonesian). Edu Geogr., 7(1): 75-82. https://journal.unnes.ac.id/sju/index.php/edugeo/article/ view/30137.

[20] Maulana, E., Wulan, T.R., Wahyuningsih, D.S., Mahendra, I.W.W.Y., Siswanti, E. (2016). Abrasion risk reduction strategy on the Rembang Regency's Coastal, Central Java (in Indonesian). In Proceedings of the 2016 UMS National Geography Seminar: Disaster Risk Reduction Efforts Related to Climate Change (in Indonesian), $\quad$ pp. 389-398. https://publikasiilmiah.ums.ac.id/handle/11617/8577.

[21] Wahyuningsih, D.S., Maulana, E., Wulan, T.R., Ambarwulan, W., Putra, M.D., Ibrahim, F., Setyaningsih, Z., Putra, A.S. (2012). Effectiveness of ecosystem-based abrasion mitigation efforts in Kulonprogo regency, special region of Yogyakarta (in Indonesian). In Proceedings of the National Marine Seminar, pp. 255$260 . \quad \mathrm{http}: / /$ ilmukelautan.trunojoyo.ac.id/wpcontent/uploads/2016/08/35_Prosiding_semnaskel_201 6.pdf.

[22] Tobey, J., Rubinoff, P., Robadue Jr, D., Ricci, G., Volk, R., Furlow, J., Anderson, G. (2010). Practicing coastal adaptation to climate change: Lessons from integrated coastal management. Coastal Management, 38(3): 317335. https://doi.org/10.1080/08920753.2010.483169

[23] Joesidawati, M.I., Suwarsih. (2019). Causes of coastal erosion and environmental damage on the Sowan beach of Tuban district. Int. J. Appl. Eng. Res, 14(12): 29502957. https://doi.org/10.37622/ijaer/14.12.2019.29522959

[24] Shidqi, M.M., Sugiri, A. (2015). Forms of environmental adaptation to abrasion in Sigandu Batang beach area (in Indonesian). J. Tek. PWK, 4(4): 702-715. https://ejournal3.undip.ac.id/index.php/pwk/article/view $/ 10131$.

[25] Widiastuti, M.M.D., Ruata, N., Arifin, T. (2018). Community understanding and participation in mangrove ecosystem management on the Arafura Sea Coast, Merauke Regency (in Indonesian). Sosek KP, 13(1): 111-123. http://ejournalbalitbang.kkp.go.id/index.php/sosek/article/view/6853.

[26] Kurniawan, E., Suharini, E., Dafip, M. (2021). How far disaster management implemented toward flood preparedness: A lesson learn from youth participation assessment in Indonesia. International Journal of Safety and Security Engineering, 11(2): 175-183. https://doi.org/10.18280/ijsse.110206

[27] Hidayati, N. (2017). Beach Dynamics (in Indonesian). Malang: UB Press. https://opac.perpusnas.go.id/DetailOpac.aspx?id=99585 6.

[28] Dimyati, M., Trihatmoko, E., Marfai, M.A. (2021). 10 years erosion-sedimentation monitoring: System based automatic interpretation in coastal area of brebes regency, Central Java Province, Indonesia. Geographia Technica, 16(1): 25-38. https://doi.org/10.21163/GT_2021.161.03

[29] Trihatmoko, E. (2017). Process and impact of the dynamics of the Coastal Region of Central Java and the special region of Yogyakarta (in Indonesian). Universitas Gadjah

Mada. http://etd.repository.ugm.ac.id/penelitian/detail/110463.

[30] Rizzo, A., Anfuso, G. (2020). Coastal dynamic and evolution: Case studies from different sites around the world. Water, 12(10): 2829. https://doi.org/10.3390/w12102829

[31] Subagiyo, A., Wijayanti, W.P., Zakiyah, D.M. (2017). Management of Coastal Zone and Small Islands. Malang, UB

Press. 
https://opac.perpusnas.go.id/DetailOpac.aspx?id=11448 19.

[32] Firdaus, Hardjosoekarto, S., Lawang, R.M.Z. (2021). The role of local government on rural tourism development: Case study of Desa Wisata Pujonkidul, Indonesia. International Journal of Sustainable Development and Planning, 16(7): 1299-1307. https://doi.org/10.18280/ijsdp.160710

[33] LPSPL Sorong. Policy on Utilization of coastal areas and small islands in relation to environmental management (in Indonesian). Directorate General of Marine Spatial Management, Ministry of Marine Affairs and Fisheries of Indonesia, 2020

https://kkp.go.id/djprl/lpsplsorong/artikel/25912kebijakan-pemanfaatan-wilayah-pesisir-dan-pulaupulau-kecil-kaitannya-dengan-pengelolaan-lingkunganhidup.

[34] Rosardi, R.G., Prajanti, S.D.W., Atmaja, H.T., Juhadi. (2021). Sustainable tourism model in Pagilaran Tea Plantation Agrotourism, in Indonesia. International Journal of Sustainable Development and Planning, 16(5): 981-990. https://doi.org/10.18280/ijsdp.160519

[35] Widadi, B., Hamid, N., Savitri, F.M., Perwita, A.D., Barreto, D.M.B. (2021). Customer loyalty establishment model based on corporate social responsibility (CSR) program in Timor Leste. Webology, 18(3): 299-321. https://doi.org/10.14704/WEB/V18SI03/WEB18042

[36] Estes, J.E. (1974). Imaging with photographic and nonphotographic sensor systems. Remote Sensing Tehciques for Environtmental Analysis, Hamilton Publishing Company, 15-50.

[37] Annisa, A., Setyowati, D.L. (2019). Community capacity in landslide disaster risk reduction. Edu Geogr., 7(1): 8394.

https://journal.unnes.ac.id/sju/index.php/edugeo/article/ view/30138/13293.

[38] Juhadi, J., Santoso, A.B., Ananda, Y.R. (2019). Assessment of community capacity in reducing disaster vulnerability of mount Ungaran Eruption, Central Java (in Indonesian). Prosiding Pertemuan Ilmiah Tahuan (PIT) XX Ikatan Geograf Indonesia (IGI) Tahun 2018. http://ejournal.unima.ac.id/index.php/pitigi2018.

[39] Hadi, S. (2000). Statistics Volume 1 (in Indonesian). Yogyakarta: Andi Offset https://onesearch.id/Record/IOS2862.UNMAL0000000 00033604.

[40] Kadar, D., Sudijono, S. (1993). Geological Map Sheet Rembang, Java. 1:100,000 Scale (in Indonesian). Bandung.

https://onesearch.id/Record/IOS1.INLIS000000000051 00 .

[41] Trihatmoko, E., Wiguna, H.S., Juhadi, J., Sunarto, S., M. Marfai, A. (2020). Discovering the river outlet current by using simple field measurement (Case study of Kendal Coastal Area). IOP Conf. Ser. Earth Environ. Sci., 451(1): 1-7. https://doi.org/10.1088/1755-1315/451/1/012074

[42] Setiady, E., Usman, E. (2008). The advancement of the coastline due to the sedimentation process along the coastal waters of rembang regency. J. Geol. Kelaut., 6(3): 146-153. http://dx.doi.org/10.32693/jgk.6.3.2008.158

[43] Feka, N.Z., Ajonina, G.N. (2011). Drivers causing decline of mangrove in West-Central Africa: A review. International Journal of Biodiversity Science, Ecosystem
Services \& Management, 7(3): 217-230. https://doi.org/10.1080/21513732.2011.634436

[44] Naharuddin, N. (2021). The critical level of mangrove ecosystem in Lariang watershed downstream, West Sulawesi-Indonesia. International Journal of Sustainable Development and Planning, 16(5): 841-851. https://doi.org/10.18280/ijsdp.160505

[45] Marois, D.E., Mitsch, W.J. (2015). Coastal protection from tsunamis and cyclones provided by mangrove wetlands-a review. International Journal of Biodiversity Science, Ecosystem Services \& Management, 11(1): 7183. https://doi.org/10.1080/21513732.2014.997292

[46] Cialdea, D. (2020). Landscape features of costal waterfronts: Historical aspects and planning issues. Sustainability, $12(6)$ : 2378. https://doi.org/10.3390/su12062378

[47] Mohammed, S., Abdo, H.G., Szabo, S., Pham, Q.B., Holb, I.J., Linh, N.T.T., Rodrigo-Comino, J. (2020). Estimating human impacts on soil erosion considering different hillslope inclinations and land uses in the coastal region of Syria. Water, 12(10): 2786. https://doi.org/10.3390/w12102786

[48] Finkl, C.W., Makowski, C. (2010). Increasing sustainability of coastal management by merging monitored marine environments with inventoried shelf resources. International Journal of Environmental Studies, 67(6): 861-870. https://doi.org/10.1080/00207230902916786

[49] Hamid, N., Roehrig, G., Liesnoor, D., Rachmah, H., Royyani, M.A., Hanifah, M. (2021). Development model for environment-based learning to improve junior high school students' geographical skills. Review of International Geographical Education Online, 11(2): 461-481. https://doi.org/10.33403rigeo.833857

[50] Setyowati, D.L., Adhi, M.A., Sidiq, W.A.B.N., Pratiwi, E.S., Trihatmoko, E. (2020). Spatial information learning to improve consciousness and attitude towards disasters. Geomate J., 18(67): 162-167. https://doi.org/10.21660/2020.67.ICGeo6

[51] Hallegatte, S. (2014). Natural Disasters and Climate Change: An Economic Perspective. Wasington, DC, USA: Springer. https://doi.org/10.1007/978-3-31908933-1

[52] Bhuiyan, S.H. (2011). Social capital and community development: An analysis of two cases from India and Bangladesh. Journal of Asian and African Studies, 46(6): 533-545. https://doi.org/10.1177/0021909611401511

[53] Juhadi, J., Hamid, N., Trihatmoko, E., Herlina, M., Aroyandini, E.N. (2021). Developing a model for disaster education to improve students' disaster mitigation literacy. J. Disaster Res., 16(8): 1243-1256. 2021, https://doi.org/10.20965/jdr.2021.p1243

[54] Shaw, R., Takeuchi, Y., Gwee, Q.R., Shiwaku, K. (2011). Disaster education: An introduction. In Disaster education. Emerald Group Publishing Limited, 7: 1-22. https://doi.org/10.1108/S2040-7262(2011)0000007007

[55] Cadag, J.R.D., Gaillard, J.C. (2012). Integrating knowledge and actions in disaster risk reduction: The contribution of participatory mapping. Area, 44(1): 100109. https://doi.org/10.1111/j.1475-4762.2011.01065.x

[56] Klopfer, A.N. (2017). 'Choosing to stay' hurricane Katrina narratives and the history of claiming placeknowledge in New Orleans. Journal of Urban History, 
43(1):

115-139.

https://doi.org/10.1177/0096144215576332

[57] Tedeschi, J.T., Lindskold, S., Rosenfeld, P. (1985). Introduction to Social Psychology. West Publishing Co.

[58] Setyowati, D.L., Astuti, T.M.P., Hardati, P., Subiyanto, S., Amin, M. (2020). The ability of tree in absorbing carbon dioxide emissions in the campus of Universitas Negeri Semarang. Int. J. Adv. Sci. Technol., 29(6): $2137-$ 2142.

[59] Muttarak, R., Pothisiri, W. (2013). The role of education on disaster preparedness: Case study of 2012 Indian Ocean earthquakes on Thailand's Andaman Coast. Ecology and Society, 18(4): 51. http://dx.doi.org/10.5751/ES-06101-180451

[60] Kearney, J., Berkes, F., Charles, A., Pinkerton, E., Wiber, M. (2007). The role of participatory governance and community-based management in integrated coastal and ocean management in Canada. Coastal Management, $35(1)$ :

$79-104$. https://doi.org/10.1080/10.1080/08920750600970511

[61] Sabani, W., Juhadi, J., Trihatmoko, E. (2021). Participatory mapping of tsunami evacuation routes (Case study of Karangbenda Village Cilacap Regency. IOP Conf. Ser. Earth Environ. Sci., 884(1). https://doi.org/10.1088/1755-1315/884/1/012033

[62] Nafisah, D., Setyowati, D.L., Banowati, E., Priyanto, A.S. (2021). Collaborative governance for management of water and air pollution caused by industrial activities in Lamongan Regency, East Java. Journal of Environmental Management \& Tourism, 12(5): 1343-1352. https://doi.org/10.14505//jemt.12.5(53).19

[63] Hamid, N., Setyowati, D.L., Juhadi, J., Priyanto, A.S., Suswanti, S., Royyani, M.A., Aroyandini, E.N. (2021). Sustainable development of the coastal environment through participatory mapping of abrasion-prone areas. J. Environ. Manag. Tour., XII(5): 1997-2009. https://doi.org/10.14505/jemt.v12.7(55).24

[64] Aly, M.N., Hamid, N., Suharno, N.E., Kholis, N., Aroyandini, E.N. (2021). Community involvement and sustainable cave tourism development in Tulungagung region. J. Environ. Manag. Tour., 12(2): 588-597. https://doi.org/10.14505//jemt.v12.2(50).28

[65] Setyowati, D.L., Trihatmoko, E., Wijayanto, P.A., Amin, M. (2020). Simulating water efficiency management at UNNES campus, Semarang, Indonesia using EDGE application. IOP Conf. Ser. Earth Environ. Sci., 485(012038): 1-7. https://doi.org/10.1088/1755$1315 / 485 / 1 / 012038$ 